\title{
Optimum Immobilization of Candida Antartica B Lipase on Natural Silica by RSM
}

\author{
Djossou Andriano Jospin ${ }^{1}$, Mazou Mouaïmine ${ }^{1}$, Tchobo Fidèle Paul ${ }^{1}$, \\ Toukourou Akanho Chakirou ${ }^{2}$, Blin Joel ${ }^{3}$, Yao Kouassi Benjamin ${ }^{4}$, \\ Soumanou Mansourou Mohamed ${ }^{1}$ \\ ${ }^{1}$ Unit of Research in Enzymatic and Food Engineering (URGEA), Polytechnic School of Abomey-Calavi (EPAC), Cotonou, Bénin \\ ${ }^{2}$ Laboratory of Energy and Applied Mechanics (LEMA), Polytechnic School of Abomey-Calavi (EPAC), Cotonou, Bénin \\ ${ }^{3}$ Mixed Unit of Research Engineering of Agropolymères and Emergent Technologies, (UMRIATE / CIRAD), Montpellier, France \\ ${ }^{4}$ Laboratory of Industrial Processes, of Synthesis, of Environment and New Energies, Yamoussoukro, Côte d'Ivoire
}

Email address:

msoumanoufr@yahoo.fr (S. M. Mohamed)

\section{To cite this article:}

Djossou Andriano Jospin, Mazou Mouaïmine, Tchobo Fidèle Paul, Toukourou Akanho Chakirou, Blin Joel, Yao Kouassi Benjamin, Soumanou Mansourou Mohamed. Optimum Immobilization of Candida Antartica B Lipase on Natural Silica by RSM. American Journal of Chemical Engineering. Vol. 5, No. 3, 2017, pp. 43-48. doi: 10.11648/j.ajche.20170503.13

Received: February 22, 2017; Accepted: March 30, 2017; Published: May 23, 2017

\begin{abstract}
The immobilization of the lipase of Candida antartica B (LCAB) by adsorption on a natural silica support carried out to develop the adsorbent local supports. Immobilization conditions and characterization of the immobilized enzyme were investigated. Response surface methodology (RSM) and 3-level-3-factor fractional factorial design were employed to evaluate the effects of immobilization parameters, such as immobilization time (5-25 hour), immobilization temperature $\left(25-45^{\circ} \mathrm{C}\right)$, and enzyme/support ratio (0.1-0.5, w/w), on yield of lipase immobilization on the support. The optimum immobilization conditions were as follows: immobilization time 18 hours, immobilization temperature $20^{\circ} \mathrm{C}$, and enzyme / support ratio 0.5 (w/w); with a yield immobilization of $56,13 \mathrm{mg} / \mathrm{g}$. The immobilization lipase shows hydrolytic and synthesis satisfactory activity.
\end{abstract}

Keywords: Immobilization, Lipase, Natural Silica Support, RSM

\section{Introduction}

The reduction in the fossil fuel reserves and the constant increase in the consumption of energy stimulated the interest of research for the renewable sources of energies. The biodiesel is one of the most promising alternatives. It showed its capacity to answer the energy demand in several fields [1]. Among all the methods of production of biodiesel, the transesterification is most effective and most significant. It is about a process in which vegetable oils, animal fat or oils containing microalgae are mixed with an alcohol (ethanol or methanol) in the presence of a catalyst, chemical (acid or bases) or enzymatic [2]. The vegetables oils most used are mainly those of sunflower, colza, soya, Jatropha or palm [3].

The use of the enzymes (lipases) as catalysts in the production of biodiesel overcomes the problems inherent in chemical catalysts. It offers an optimal reactional environment ecological. However, in spite of the advantages of employing enzymes, the factories of biodiesel using lipases are not yet a reality on an industrial scale. The reason of this is that there are some challenges which must be still overcome before biocatalysis can be made feasible for the production of biodiesel, such as their cost, the productivity of biodiesel, and inhibition more raised by the reagents and the products. The immobilization of the enzymes proves to be an approach of solution for to confine them into the reactor in order to reuse the biocatalyst for several reaction cycles. Immobilization of enzymes plays an important part within applied biotechnology. Different techniques for the immobilization of lipase have been tried and reviewed by several workers including adsorption $[4,5,6,7,8]$, covalent binding $[4,9,10]$ and entrapment within a polymer matrix or hydrophobic sol-gel materials [11, 12]. Among all these different methods, adsorption remains the simplest method and more profitable [13]. These various supports showed a compatibility with lipase. In addition to their low cost, these 
supports are characterized by their lack of toxicity and chemical reactivity with the enzyme. [14]. This study falls under same dynamics by the valorization of the natural supports having properties absorbing. The aim of the present work was to produce an immobilized lipase from Candida antartica $\mathrm{B}$. The lipase was immobilized on non-commercial support by adsorption and the optimal conditions of immobilization were defined by RSM. The activity of modified lipase has been studied in comparison with the free enzyme.

\section{Materials}

Lipase powder from Candida Antarctica B from Amano Enzyme Inc. (Nagoya, Japan) was used as catalysts. Oleic acid and Jatropha curcas oil were used as substrate and ethanol was used for reaction. Jatropha curcas oils it was obtained by the Soxhlet method and the support was provided by (Laboratory of applied Energetic and Mechanic (LEMA in Benin). The Other chemical reagents and solvents were of analytical grade.

\section{Methods}

\subsection{Experimental Design}

\subsubsection{Construction of the Sifting Plan and Realization of the Tests}

The main parameters influencing the yield of the immobilization process are temperature $\mathrm{T}\left(25-45^{\circ} \mathrm{C}\right)$, time $\mathrm{t}$ (5-25 hours), $\mathrm{pH}$ (5.5-8.5), agitation speed $\mathrm{Vg}$ (100-300 rpm), buffer volume Vtp (20-30 ml) and enzyme/support ratio (0.2-0.6). These parameters are not independent of each other and optimization requires multi-factor models, involving the use of experimental plans. To achieve this, a screening plan (Plackett and Burman) was proposed. It has already been used in studies similar to ours $[15,16]$ because of its economy in terms of the number of trials. Table 1 presents the experimental matrix and the answers obtained for each level of the plan. Data processing was carried out by multiple linear regression, the effect values and the regression coefficients of model were synthesized in a table to identify the most influential parameters.

Table 1. Experimental design and answers obtained.

\begin{tabular}{|c|c|c|c|c|c|c|c|c|c|}
\hline $\mathbf{N}^{\circ}$ & $\mathbf{T}\left({ }^{\circ} \mathbf{C}\right)$ & t (hour) & pH & Vg (rpm) & Vtp (ml) & $\mathbf{E} / \mathbf{S}(\mathbf{w} / \mathbf{w})$ & g protein per gram of support (g/g) & g protein fixed (g/g) & $Y(\%)$ \\
\hline 1 & 25 & 5 & 5.5 & 300 & 30 & 0.6 & 0.482 & 0.11512 & 23.88 \\
\hline 2 & 25 & 5 & 5.5 & 100 & 20 & 0.2 & 0.095 & 0.040 & 42,10 \\
\hline 3 & 25 & 5 & 8.5 & 300 & 30 & 0.2 & 0.104 & 0.032 & 30.71 \\
\hline 4 & 45 & 5 & 8.5 & 300 & 20 & 0.6 & 0.487 & 0.115 & 23,61 \\
\hline 5 & 45 & 25 & 5.5 & 300 & 30 & 0.2 & 0.975 & 0.089 & 9.85 \\
\hline 6 & 25 & 25 & 8.5 & 100 & 30 & 0.2 & 0.849 & 0.0204 & 24.04 \\
\hline 8 & 45 & 5 & 8.5 & 100 & 20 & 0.2 & 0.089 & 0.008 & 8.89 \\
\hline 9 & 25 & 25 & 5.5 & 100 & 20 & 0.6 & 0.473 & 0.2324 & 49,13 \\
\hline 10 & 45 & 5 & 5.5 & 100 & 30 & 0.6 & 0.469 & 0.0202 & 4.30 \\
\hline 11 & 45 & 25 & 8.5 & 100 & 30 & 0.6 & 0.419 & 0.152 & 36.27 \\
\hline 12 & 45 & 25 & 5.5 & 300 & 20 & 0.2 & 0.088 & 0.0182 & 20.68 \\
\hline
\end{tabular}

\subsubsection{Optimization by Box-Behnken Plan}

The selection of the immobilization variable range needs to be extremely precise in the 3-level-3-factor fractional design; otherwise, the optimal condition of immobilization cannot be found inside the experimental region by analyses of statistics and contour plots. Therefore, the variables and their levels selected for lipase immobilization study were: immobilization time (5-15 hour), immobilization temperature $\left(25-45^{\circ} \mathrm{C}\right)$, and enzyme/support ratio $(0.1-0.5$, w/w). A 3level-3-factor fractional factorial design was employed in this study, requiring 15 experiments. Table 2 shows the independent factors (x), levels and experimental design in terms of coded $(0,1$, and -1$)$ and uncoded (actual value). To avoid bias, 15 runs were performed in a totally random order.

\subsection{Immobilization of Lipase}

Crude lipase/support (0.1-0.5 w/w) was dissolved in $5 \mathrm{ml}$ of buffer solution $(0.1 \mathrm{~mol} / \mathrm{L}, \mathrm{pH} 7.3)$ and mixed. The mixture was stirred for various immobilization times (5-15 hour) at immobilization temperatures $\left(25-45^{\circ} \mathrm{C}\right)$. The immobilized lipase was collected by filtration and washed twice with the same buffer under reduced pressure, and then one dried at room temperature. Consequently, the residue was obtained which is immobilized lipase on support.

The immobilization efficiency was evaluated in terms of protein yields by measuring the difference between the protein concentration in the lipase solution before and after immobilization according to the following equation:

Protein immobilization yield $(\%)=\left(\mathrm{C}_{\mathrm{i}}-\mathrm{C}_{\mathrm{f}}\right) / \mathrm{C}_{\mathrm{i}}$; where $\mathrm{Ci}$ is the initial protein concentration in the lipase solution, and $\mathrm{C}_{\mathrm{f}}$ is the final protein concentration in solution after immobilization. The protein concentration was measured according to the method using bovine serum albumin (BSA) as the standard [17]. 
Table 2. Fractional factorial design and observed experimental data for 3-level-3-factor response surface analysis.

\begin{tabular}{|c|c|c|c|c|c|}
\hline \multirow{2}{*}{$\mathbf{N}^{\circ}$} & \multicolumn{3}{|c|}{ Factors } & \multirow{2}{*}{ Experimental values of immobilized yield $(\mathrm{mg} / \mathrm{g})$} & \multirow{2}{*}{ Predicted values of immobilized yield $(\mathrm{mg} / \mathrm{g})$} \\
\hline & $\mathrm{x}_{1}$ & $\mathrm{x}_{2}$ & $\mathbf{x}_{3}$ & & \\
\hline 1 & 12 & 32.5 & 0.3 & 45.96 & 43.537 \\
\hline 2 & 12 & 45 & 0.1 & 12.168 & 11.673 \\
\hline 3 & 18 & 32.5 & 0.1 & 25.67 & 23.159 \\
\hline 4 & 6 & 32.5 & 0.5 & 22.86 & 25.372 \\
\hline 5 & 18 & 32.5 & 0.5 & 51.65 & 51.117 \\
\hline 6 & 12 & 45 & 0.5 & 26.51 & 24.037 \\
\hline 7 & 12 & 32.5 & 0.3 & 41.23 & 43.537 \\
\hline 8 & 18 & 20 & 0.3 & 56.01 & 56.049 \\
\hline 9 & 6 & 45 & 0.3 & 17.34 & 17.301 \\
\hline 10 & 12 & 20 & 0.5 & 52.14 & 52.635 \\
\hline 11 & 6 & 32.5 & 0.1 & 15.96 & 16.494 \\
\hline 12 & 12 & 20 & 0.1 & 25.69 & 28.162 \\
\hline 13 & 12 & 32.5 & 0.3 & 43.42 & 43.537 \\
\hline 14 & 6 & 20 & 0.3 & 26.46 & 23.454 \\
\hline 15 & 18 & 45 & 0.3 & 14.11 & 17.116 \\
\hline
\end{tabular}

$\mathrm{x}_{1}$ : Time (hour); $\mathrm{x}_{2}$ : temperature; $\mathrm{x}_{3}$ : enzyme/support ratio $(\mathrm{w} / \mathrm{w})$

\subsection{Measurement of Lipase Activity}

\subsubsection{Hydrolytic Activity}

The hydrolytic activities of free and immobilized lipase were assayed by Jatropha curcas oil emulsion method, according to the modification proposed by Soares et al., [9]. The reactions of hydrolysis of free and immobilized lipases were performed in screw-capped flasks containing $1 \mathrm{~g}$ oil diluted in $5 \mathrm{ml}$ of cyclohexane to which one adds $20 \mu \mathrm{L}$ of a calcium chloride solution (02M) and $50 \mu \mathrm{L}$ of the enzymatic solution $(3 \mathrm{mg} / \mathrm{L})$ prepared in sodium phosphates buffer $(\mathrm{pH}$ $=7$ ). The mixture thus obtained was mixed under stirring (300 rpm) for $30 \mathrm{mn}$ at room temperature. The reaction stops when one adds $35 \mathrm{ml}$ of a ethanol/acetone mixture. Free acidity is titrated (V) with a solution welds (C) in the presence of phenolphthalein against a white (Vo) without enzyme. The enzymatic activity (AE) is expressed in mole of free fatty acids which releases one $\mathrm{mg}$ of enzyme for unit of time according to the following formula: $\mathrm{AE}=(\mathrm{C}(\mathrm{V}-\mathrm{Vo})) /$ $(\mathrm{m} \times \mathrm{t})$, with $\mathrm{m}$ mass of enzyme in the enzymatic solution.

\subsubsection{Esterification Assay}

The esterification reactions were performed in screw- capped flasks with a molar ratio of oleic acid to ethanol 1:1 (0.4 mmol of oleic acid and $0.8 \mathrm{mmol}$ of ethanol), of immobilized lipase dissolved in $4 \mathrm{ml}$ of anhydrous n-hexane. The reaction mixture was shaken for $48 \mathrm{~h}$ at $220 \mathrm{rpm}$ at $37^{\circ} \mathrm{C}$ in a shaking incubator and titrated with $0.5 \mathrm{~N}$ sodium hydroxide, using phenolphthalein as an indicator and $2 \mathrm{ml}$ of ethanol as a quenching agent. The conversion (\%) in ester synthesis was based on acid consumed [18].

\subsubsection{Enzymatic Synthesis of Biodiesel}

The enzymatic transesterification reactions were carried out in a 50-mL shaking flask under magnetic stirring at 180 $\mathrm{rpm}$ at $40^{\circ} \mathrm{C}$ for $48 \mathrm{~h}$, using a ratio (J. curcas oil: ethanol $)=$ $(1: 10)$; free or immobilized lipase $=5 \%$ of $J$. curcas oil. The ethyl ester contents in the reaction mixture were quantified using a Gas Chromatograph coupled to a mass spectrometer (Perkin Elmer Clarus GC680-MS600C).

\subsection{Statistical Analysis}

The experimental data (Table 1) were analyzed by the response surface regression procedure to fit the following second-order polynomial equation Statistica:

$$
Y=a_{0}+\sum_{i=1}^{3} a_{i} x_{i}+\sum_{i=1}^{3} a_{i i} X_{i}^{2}+\sum_{i=1}^{2} \sum_{j=i+1}^{3} a_{i j} x_{i} x_{j}
$$

where $\mathrm{Y}(\mathrm{mg} / \mathrm{g})$ is response (immobilization yield); $\mathrm{a}_{\mathrm{o}}, \mathrm{a}_{\mathrm{i}}$ and $a_{i j}$ are constant coefficients and $x_{i}$ and $x_{j}$ the uncoded independent variables. The signs of these coefficients are used to highlight the synergy (+ sign) and the antagonist (sign) variables controls. The results were statistically processed by analysis of variance to assess the influence of the control variables on the responses observed.

\section{Results and Discussion}

\subsection{Analysis of the Screening Results of Immobilization Parameters}

Data processing was performed by multiple linear regression using the Minitab software. The values of the effects and the regression coefficients of the model are given in Table 3

Table 3. Effect and estimated coefficients for the response.

\begin{tabular}{llll}
\hline Term & Effet & Coefficient & Probability $(\mathbf{p}<\boldsymbol{\alpha}=\mathbf{0 . 0 5})$ \\
\hline Constant & & 0.09788 & 0.001 \\
Temperature $\left({ }^{\circ} \mathrm{C}\right)$ & -0.07302 & -0.03651 & 0.032 \\
Time (hour) & 0.08465 & 0.04232 & 0.019 \\
$\mathrm{pH}$ & -0.03151 & 0.01576 & 0.258 \\
$\begin{array}{l}\text { Agitation speed } \\
\text { (rpm) }\end{array}$ & 0.00642 & 0.00321 & 0.805 \\
buffer solution $(\mathrm{ml})$ & -0.06485 & -0.03242 & 0.047 \\
Ratio (E/S) & 0.15029 & 0.07514 & 0.002 \\
\hline
\end{tabular}

These results show that among all the factors studied, only the $\mathrm{pH}$ and the agitation speed have no significant influence 
on the response at the chosen confidence level $(\alpha=0.05)$. This plan allows us to observe that the $\mathrm{pH}$ does not significantly influence the adsorption of the lipases on the support. However, its negative effect means that, at low $\mathrm{pH}$, low levels of protein binding are present. At these $\mathrm{pH}$ values, the protein is weakly ionized and therefore its adsorption by the support is low. For these reasons, we decided to set the $\mathrm{pH}$ neutrality. Also, the buffer volume affects negatively the response. This result can be explained by a large diffusion of the reagents in the medium which would not favor the fixation of the enzymes on the support. So we decided to fix it at its small value, $25 \mathrm{ml}$. Statistically, this is the least influential factor. Since it is a parameter generally described as important by many authors we decided to fix it at its high value $(300 \mathrm{rpm})$. In conclusion, the three factors selected for optimization by the Box -Behnken plan are time, temperature and ratio $(\mathrm{E} / \mathrm{S})$.

\subsection{Immobilization Parameters}

The effects of immobilization parameters, immobilization time and temperature and enzyme / support ratio, on immobilization yield were investigated. The figure 1, 2, 3 shows the effects of these factors on immobilization. The analysis of figure 1 shows an exponential increase in the immobilization yield from 5 to 15 agitation time of. Beyond, the yield does not increase significantly. The adsorption was limited when the immobilization time was short. The immobilization is also affected by the temperature (fig. 2). It increases by 51.22 to $59.73 \mathrm{mg} / \mathrm{g}$ corresponding respectively to temperatures 25 and $35^{\circ} \mathrm{C}$ then decreases drastically to $20.57 \mathrm{mg} / \mathrm{g}$. Similar phenomenon was reported with lipase immobilized by several authors [19, 20, 21]. Besides, the analysis of this figure 3 shows a progressive increase of immobilization yield of the enzyme/support ratio 0.2 (13.59 $\mathrm{mg} / \mathrm{g})$ at the ratio enzyme/support $0.5(54.3 \mathrm{mg} / \mathrm{g})$. It increases then at $57.14 \mathrm{mg} / \mathrm{g}$ for the ratio enzyme/support 0.6 . But this increase is not highly significantly.

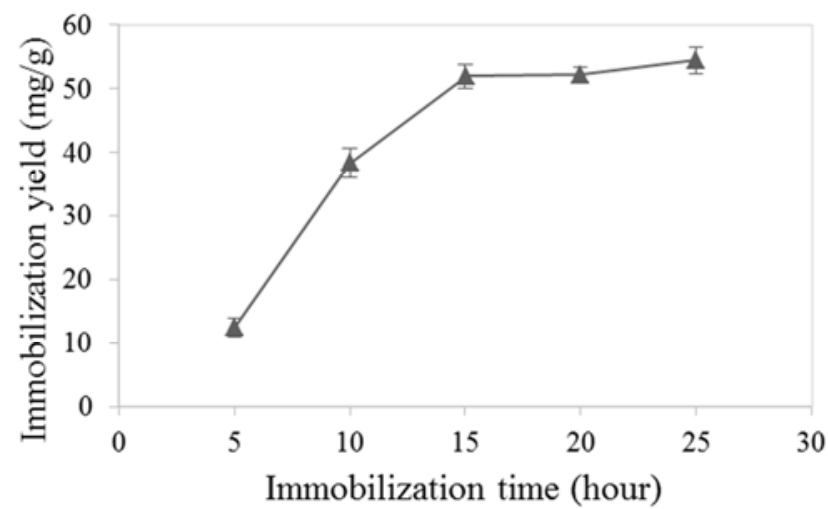

Figure 1. The effect of immobilization time on the immobilization yield. Immobilization was carried out for $37^{\circ} \mathrm{C}$ with $5 \mathrm{ml}$ buffer ( $\left.\mathrm{pH} 7,3\right), 0.5 \mathrm{~g}$ $L C A B$ and $1 \mathrm{~g}$ of support.

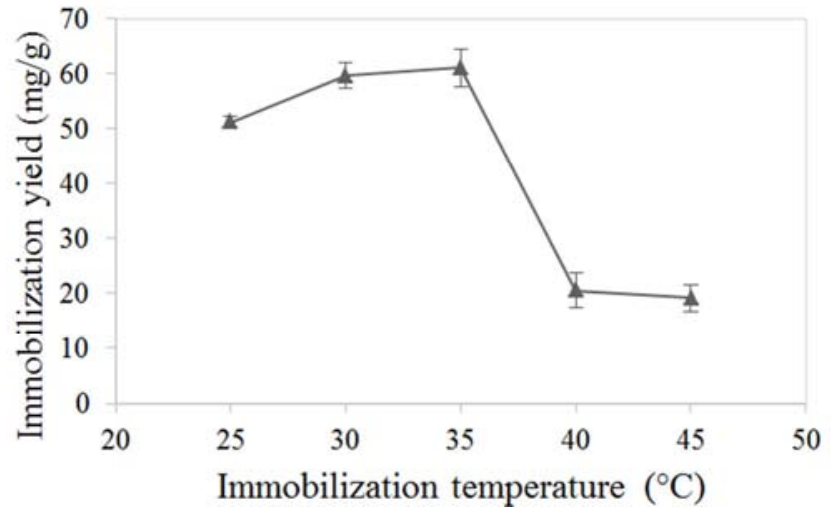

Figure 2. The effect of immobilization temperature on the immobilization yield. Immobilization was carried out for 24 hours with $5 \mathrm{ml}$ buffer ( $\mathrm{pH} 7.3$ ), $0.5 \mathrm{~g} L C A B$ and $1 \mathrm{~g}$ of support.

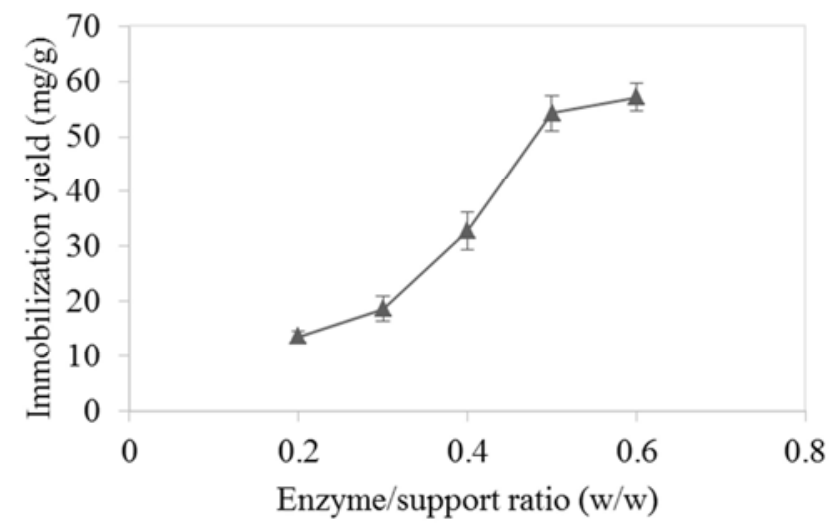

Figure 3. The effect of immobilization temperature on the immobilization yield. Immobilization was carried out for 24 hours at $37^{\circ} \mathrm{C}$ with $5 \mathrm{ml}$ buffer ( $p H$ 7.3).

\subsection{Model Fitting and Mutual Effect of Parameters}

The response surface regression procedure for Statistica software was employed to fit the second-order polynomial equation (2) to the experimental data, represented as immobilization yield (Table 1)because the real relationship between response and factors was either unknown or too complex., The output of the response surface regression procedure is given by the second-order polynomial equation 2 below

$$
\begin{gathered}
Y=43.537+8.102 x_{1}-11.272 x_{2}+9.209 x_{3}-7.574 x_{1}{ }^{2}-7.482 x_{2}{ }^{2}- \\
6.927 x_{3}{ }^{2}-8.195 x_{1} x_{2}+4.77 x_{1} x_{3}-3.027 x_{2} x_{3}
\end{gathered}
$$

With $\mathrm{x}_{1}$, immobilization time, $\mathrm{x}_{2}$ immobilization temperature, $x_{3}$ enzyme/support ratio.

The analysis of variance (ANOVA) from table 3 indicated that the second-order polynomial model (equation 2) was statistically significant and adequate to represent the actual relationship between the response (immobilization yield) and the significant variables, with very small $p$-value $(0.001)$ and satisfactory coefficient of determination $\left(\mathrm{R}^{2}=0.983\right)$. Furthermore, the all parameters (immobilization time, immobilization temperature, and enzyme/support ratio) and the interaction immobilization time-immobilization temperature and immobilization time-enzyme/support ratio 
were the important factors which exerting a statistically significant overall effect $(p<0.01)$ on the response.

The relationships between immobilization factors and response can be better understood by examining the series of contour plots fig. 4, 5, 6. Immobilization time and temperature have been investigated in the range of 5-15 hour and $25-45^{\circ} \mathrm{C}$, respectively. Figure 4 shows the effect of immobilization time, temperature and their mutual interaction on the yield immobilized lipase. The analysis of this figure shows that for the low values of immobilization temperature, an increase in the immobilization time from 5 to 15 hours induced a significant increase in the immobilization yield from 10 to $50 \mathrm{mg} / \mathrm{g}$ of lipase. On the other hand, when immobilization time have been fixed, an increase in the temperature induced a reduction in the of immobilization yield. We have noticed a negative interaction between these two. It is the same for figure 6 . As regards the figure 5 , when one of the factors is fixed, an increase in the other induced a significant increases of immobilization yield.

Table 2. ANOVA for immobilization variables pertaining to the response immobilization yield.

\begin{tabular}{llll}
\hline Factor & $\begin{array}{l}\text { Degrees of } \\
\text { freedom }\end{array}$ & $\begin{array}{l}\text { Sum of } \\
\text { squares }\end{array}$ & $\begin{array}{l}\text { Prob }> \\
\mathbf{0 . 0 5 *}\end{array}$ \\
\hline Model & 9 & 3132.81 & 0.001 \\
Lineair & 3 & 2220.02 & 0 \\
Quadratic & 3 & 516.5 & 0.006 \\
Cross product & 3 & 396.29 & 0.01 \\
Lack of fit & 5 & 55.18 & \\
Pure error & 2 & 11.21 & \\
Total error & 14 & 3188 & \\
$\mathrm{R}^{2}$ & 0.983 & & \\
\hline
\end{tabular}

*Levels of significance

The interaction between these two factors has a positive effect on the immobilization. The function of desirability of the software was used to determine the optimum conditions for the process. The value of the immobilization yield $(59.13 \%)$ is estimated for 18 hours of immobilization time at $20^{\circ} \mathrm{C}$ for enzyme/support ratio of $(1: 5)$. This rate is comparable (16.85 to 84.13) with that of Gao et al., [22] in the case of the immobilization of Candida $s p$. lipase on macroporous resin and its application in synthesis of biodiesel in low aqueous media.

\subsection{Physico-Chemical Characteristic of Jatropha Curcas Oil and the Biodiesels Obtained}

Table 3 presents the hydrolytic activities, and of synthesis (esterification and transesterification) of free and immobilized catalysts. The free lipase of $C$ antarctica to a hydrolytic activity, of conversion of oleic acid and cross esterification respective of 5.94 mmole / (g. min), 91.70\% and $89.54 \%$. Immobilized on the support its activities are respectively of $2.73 \mathrm{mmole} /$ (g. $\mathrm{min}$ ), $46.54 \%$ and $46.91 \%$ of conversion of the oil of J. curcas. According to Calgaroto et al [21] [9] after the immobilization process, the mass transfer of the enzyme to the substrate can be reduced, due to the difficult of substrate to achieve the active site of the enzyme. The conversion rate obtained in this study for lipase immobilized is higher than those obtained by Gao et al, [10] for the support of polar resin KHA (16.53\%), nonpolar polar resin NKH $(25.92 \%)$ but lower than that obtained for the support of weakly polar resin $(60.98 \%)$.

Table 3. Activity of free and immobilized lipase.

\begin{tabular}{llll}
\hline Parameter & Unity & CALB free & CALB-support \\
\hline hydrolytic activity & $\begin{array}{l}\text { mmol } / \text { g. min } \\
\text { \% of oleic acid }\end{array}$ & $5.94 \pm 0.1$ & $2.73 \pm 0.1$ \\
Esterification & $\begin{array}{l}\text { conversion } \\
\text { Transesterification }\end{array}$ & $\begin{array}{l}\text { \% of conversion } \\
\text { of.70 } \pm 2.1\end{array}$ & $46.54 \pm 1.5$ \\
\hline
\end{tabular}

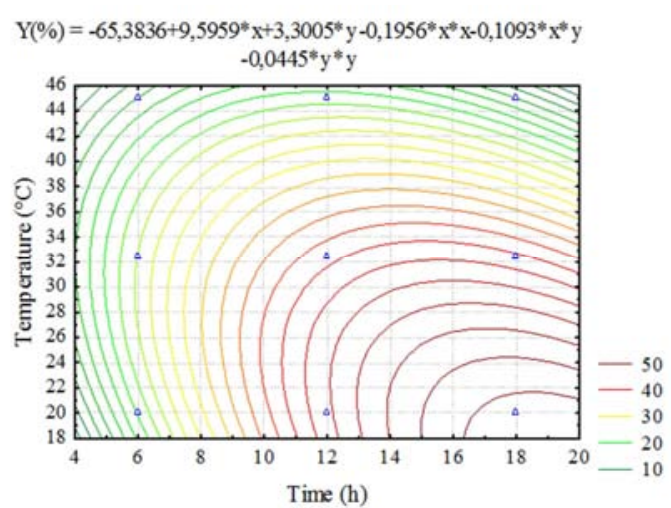

Figure 4. Iso-response curve showing the variation of immobilization yield ( $\mathrm{mg} / \mathrm{g}$ ) as immobilization time (hour) and temperature $\left({ }^{\circ} \mathrm{C}\right.$ ).

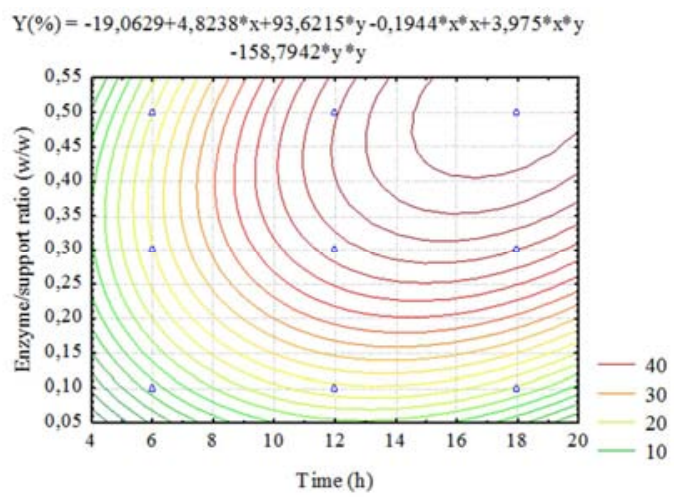

Figure 5. Iso-response curve showing the variation of immobilization yield ( $\mathrm{mg} / \mathrm{g}$ ) as immobilization time (hour) and enzyme/support ratio (w/w).

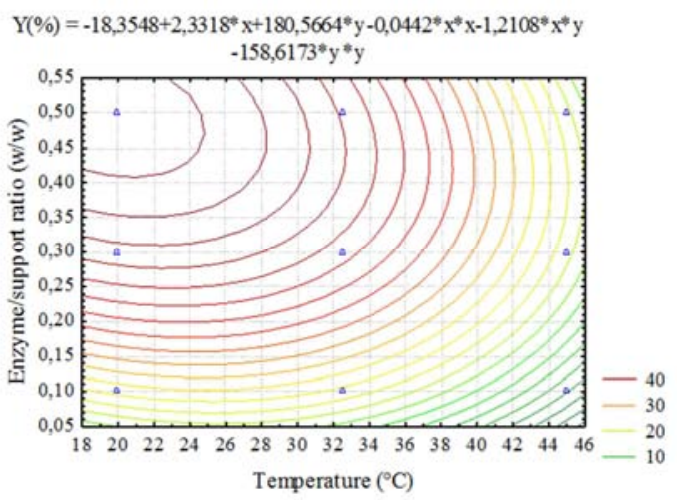

Figure 6. Iso-response curve showing the variation of immobilization yield ( $\mathrm{mg} / \mathrm{g})$ as the function of immobilization the temperature and the enzyme/support ratio $(w / w)$. 


\section{Conclusion}

Lipase from $C$. antartica B was successfully immobilized on natural silica support by adsorption in aqueous media. The optimum conditions of immobilized lipase were: immobilization time $15 \mathrm{~h}$, immobilization temperature $20^{\circ} \mathrm{C}$, and enzyme/support ratio $0.5(\mathrm{w} / \mathrm{w})$. The hydrolytic activity obtained was 5.94 and $2.73 \mathrm{mmol}$ (g.min) respectively for free and immobilized. The conversion rate into oleic acid esterification and J. curcas oil transesterification is $91.70 \%$ and $89.54 \%$ respectively for free lipase and 46.54 and 46.91 for the immobilized lipase. Lipase LCAB-support showed a promising future for various organic syntheses. The results obtained in the present study can contribute to the development of the immobilization processes of microbial lipases on natural supports. The suitable treatments of these natural supports would improve their quality, for uses as materials of immobilization of enzymes in several fields.

\section{Acknowledgement}

This publication was prepared with the assistance of PRONOVABIO and AUF. The African Union and the European Union were gratefully acknowledged.

\section{References}

[1] C. C. Akoh, S. Chang, G. Lee G, J. Shaw. "Enzymatic approach to biodiesel production", Agric Food Chem, (2007) 55: 8995-9005.

[2] S. K. Narwal, R. Gupta, "Biodiesel production by transesterification using immobilized lipase", Biotechnol Lett, 35 , (2013), 479-490.

[3] R. Richard. "Transestérification éthanolique d'huile végétale dans des microréacteurs: transposition du batch au continu ", Thèse doctorale (2011), Université de Toulouse.

[4] R. R. de Souza, R. D. M. Ferreira, "Immobilization of Lipase from Candida rugosa on Mesoporous MCM 41", Journal of Biosciences and Medicines, 2 (2014), 69-73.

[5] W. Kaewthong, S. Sarote, P. Poonsuk, H. Aran, "Continuous production of monoacylglycerols by glycerolysis of palm olein with immobilized lipase", Process Biochem, 40 (2005), 1525-1530.

[6] S. K. Khare, M. Nakajima, "Immobilization of Rhizopus japonicus lipase on celite and its application for enrichment of docosahexaenoic acid in soybean oil", Food Chem, 68 (2000), 153-157.

[7] P. C. Oliveira, G. M Alves, H. F. Castro, "Immobilisation studies and catalytic properties of microbial lipase onto styrene-divinylbenzene copolymer", Biochem. Eng. J. 5 (2000), 63-71.

[8] M. Person, E. Wehtje, P. Adlercreutz, "Immobilisation of lipases by adsorption and deposition: high protein loading gives lower water activity optimum", Biotechnol Lett. 22 (2000), 1571-1575.

[9] C. M. F. Soares, H. F. Castro, F. F. Moraes, G. M. Zanin,
"Characterization and utilization of Candida rugosa lipase immobilized on controlled pore silica", Appl. Biochem. Biotechnol. 77 (1999), 745-757.

[10] M. Miranda, M. L. C. P. Silva, H. F. de Castro "Optimised immobilisation of microbial lipase on hydrous niobium oxide", J. Chem. Technol. Biotechnol, 81 (2006), 566-572.

[11] C. M. F. Soares, O. A Santos, J. E. Olivo, H. F. Castro, F. F. Moraes, G. M. Zanin, "Influence of the alkyl-substituted silane precursor on sol-gel encapsulated lipase activity", $J$. Mol. Catal. B: Enzym. 29 (2004), 69-79.

[12] M. T. Reetz, "Lipases as practical biocatalysts", Curr. Opin. Chem. Biol. 6 (2002), 145-150.

[13] W. A. M. Alloue, M. Agouedo, J. Destain, H. Ghalft, C. Blecker, J-P. Wathelet, P. Thonart, "Les lipases immobilisées et leurs applications ", Biotechnol. Agron. Soc. Environ, 12 (2008), 57-68.

[14] P. C. M. Da Rós, G. A. M. Silva, A. A. Mendes, J. C. Santos, H. F. de Castro, "Evaluation of the catalytic properties of Burkholderia cepacia lipase immobilized on non-commercial matrices to be used in biodiesel synthesis from different feedstocks", Bioresource Technology, 101 (2010), 5508-5516.

[15] X. Zou, C. F. Chen, H. F. Hang, J. Chu, Y. P. Zhuang, S. L. Zhang, "Response Surface Methodology for optimization of the erythromycin production by fed-batch fermentation using an inexpensive biological nitrogen source", Chem. Biochem. Eng, 24 (2010), 95-100.

[16] S. F Cheng, S. W. Chang, Y. H. Yen, C. J. Hsieh, "Optimum immobilization of Candida rugosa lipase on Celite by RSM", Applied Clay Science, 37 (2007), 67-73.

[17] R. E Wrolstad, “Anthocyanins”, In F. J. Francis, G. J. Lauro, Eds. New York: Natural Food Colorants, (2000), 237-252.

[18] R. Bovara, G. O. Carrea, G. Ottolina, S. Riva, "Effects of water activity on Vmax and $\mathrm{Km}$ of lipase catalyzed transesterification in organic media", Biotechnology Letters, 15(1993): 937-942.

[19] H. Ghamgui, N. Miled, M. Karra-chaabouni, Y. Gargouri, "Immobilization studies and biochemical properties of free and immobilized Rhizopus oryzae lipase onto CaCO3: A comparative study", Biochemical Engineering Journal, 37 (2007), 34-41.

[20] A. Hiol, M. D. Jonzo, N. Rugani, D. Druet, L. Sarda, L. C. Comeau, "Purification and characterization of an extracellular lipase from a thermophilic Rhizopus oryzae strain isolated from palm fruit", Enzyme Microb. Technol, 26 (2000), 421430 .

[21] S. Montero, A. Blanco, M. D. Virto, L. C. Landeta, I. Agud, R. Solozabal, "Immobilization of Candida rugosa lipase and some properties of the immobilized enzyme", Enzyme Microb. Technol, 15 (1993) 239-247.

[22] Y. Gao, T. Tian-Wei, N. F. Kai-Li, "Wang Immobilization of lipase on macroporous resin and its application in synthesis of biodiesel in low aqueous media", Chin J Biotech, 22 (2006), 114-118.

[23] C. Calgaroto, R. P. Scherer, S. Calgaroto, J. V. Oliveira, D. de Oliveira, S. B. C. Pergher "Immobilization of porcine pancreatic lipase in zeolite MCM 22 with different $\mathrm{Si} / \mathrm{Al}$ ratios", Applied Catalysis A: General 394, (2011) 101-104. 